\title{
ISSUES IN THE APPLICATION OF RESEARCH TO PRACTICE
}

Ketefian S. Issues in the application of research to practice. Rev Latino-am Enfermagem 2001 setembro-outubro; 9(5):7-12.

In recent years calls for evidence-based practice are being made emphatically in the nursing literature worldwide. Yet, the underlying construct, which relates to use of scientifically-based knowledge and research to practice, has been with us for a long time. This analytic paper provides an overview of research utilization models developed and used in nursing and other fields, highlighting some of their features. The paper then reviews research utilization and application issues at the institutional level, highlighting the importance of organizational mechanisms for enabling optimum research use and application, rather than relying on individual nurses. It then describes ways in which research can be used at the societal level in the formation of healthy public policies, using the United States as a case study. A number of recommendations are then presented for organizations and the profession at large in a global context.

KEY WORDS: research use, knowledge utilization, evidence-based practice

\section{ASPECTOS RELACIONADOS CON LA APLICACIÓN DE LA INVESTIGACIÓN A LA PRÁCTICA}

En años recientes, la literatura de enfermería a nivel mundial ha exigido enfaticamente la práctica basada en la evidencia. Aun así, su construcción subyacente, la cual relaciona la practica a la utilización del conocimiento con base científica y el de la investigación, ya se encuentra en nuestro medio hace bastante tiempo. Este trabajo analítico ofrece un panorama de los modelos de utilización de investigación desarrollados y empleados en enfermería y otras áreas, enfatizando algunas de sus características. Él hace entonces, una revisión acerca de los aspectos relacionados con la utilización y aplicación de la investigación a nivel institucional, enfatizando la importancia de los mecanismos organizacionales con miras a hacer posible el desarrollo de condiciones optimas para el uso de la investigación, en lugar de permanecer en la dependencia de los enfermeros como individuos. Son asi descritas formas a través de las cuales la investigación puede ser utilizada a nivel social en la formación de políticas públicas saludables, teniendo los Estados Unidos como un Estudio de Caso. Varias recomendaciones son presentadas con miras a la organización y a la profesión como un todo en un contexto global.

PALABRAS CLAVE: utilización de la investigación, uso del conocimiento, práctica basada en la evidencia

\section{QUESTÕES RELACIONADAS COM A APLICAÇÃO DA PESQUISA À PRÁTICA}

Em anos recentes, a literatura de enfermagem em nível mundial tem enfaticamente exigido a prática baseada em evidência. No entanto, seu construto subjacente, o qual relaciona à prática a utilização do conhecimento cientificamente embasado e o da pesquisa, já se encontra em nosso meio há bastante tempo. Este trabalho analítico oferece um panorama dos modelos de utilização de pesquisa desenvolvidos e empregados em enfermagem e outras áreas, enfatizando algumas de suas características. Ele faz, então, uma revisão acerca das questões relacionadas à utilização e aplicação da pesquisa ao nível institucional, enfatizando a importância dos mecanismos organizacionais com vistas a possibilitar ótimas condições de uso da pesquisa em vez de permanecer na dependência de enfermeiros enquanto indivíduos. São, assim, descritas formas através das quais a pesquisa pode ser utilizada ao nivel social na formação de políticas públicas saudáveis, tendo os Estados Unidos como um estudo de caso. Várias recomendações são apresentadas com vistas à organização e à profissão como um todo em um contexto global.

TÉRMINOS CLAVES: utilização da pesquisa, uso do conhecimento, prática baseada em evidência

\footnotetext{
${ }^{1}$ EdD, RN, FAAN; Professor; Director of International Affairs - University of Michigan School of Nursing, e-mail: ketefian@umich.edu
} 
$O_{\text {ver the past several decades a general understanding }}$ and belief have evolved that in order to improve the care of people we need to apply research-based knowledge into the practice setting, now referred to as evidence-based practice. This belief underlies the development of doctoral programs worldwide, so that we have a sufficient number of individuals capable of conducting research; it is also the rationale for the creation of structures at the national level (in the United States), currently the National Institute of Nursing Research (NINR) at the National Institutes of Health, to support both research training (at the doctoral and postdoctoral levels), and to support the conduct of research through a variety of mechanisms.

Starting in the mid-seventies, nursing began paying systematic attention to knowledge utilization issues, and an impressive body of literature ensued. This literature has been widely disseminated. Many authors and leaders are now calling for evidence-based practice in nursing in order to enhance the quality of care to patients. In a document on the essentials of master's education, the American Association of Colleges of Nursing - AACN ${ }^{(1)}$ identifies the following as one of the skills of master's prepared individuals for advanced practice: "Utilize new knowledge to analyze the outcomes of nursing interventions, to initiate change, and to improve practice" ${ }^{\prime(1)}$. These are indications that the profession places high value on the application of scientific knowledge.

The number of doctoral programs internationally has increased; over 225 programs are now offered wihin 26 countries. The graduaes of these programs are generating nursing science. Yet, the extent to which this increased body of scientific work, being reported in an ever-expanding number of journals, is having a positive impact in improving the health of the people is less clear. Yet, one notes that far less attention is being devoted to deliberately bring to bear the science produced to the level of the individual nurse who can make use of it in patient care. I would submit that the concern before us is lack of a recognition that application of science to practice does not happen by itself, and that unless deliberate strategies are developed, there will be a gap between scientific knowledge and its application to practice.

A gap exists between the production of knowledge and its application. This matter of a gap has been addressed from time to time, and with varying vigor in different disciplines. A few decades ago it was estimated that there was a lag of 40-50 years between knowledge discovery and its application. More recently, knowledgeable observers estimate the lag to have decreased to about 15 years. In nursing specifically, we know a lag exists, but its dimension has not been quantified. Given the compelling health problems within our societies, can we afford any lag at all? I think not. The purpose of this paper is to review research utilization models and projects based on them, address the role of institutions in utilizing scientific knowledge in practice, describe the uses of research in public policies, ending with recommendations addressed to various sectors.
RESEARCH UTILIZATION MODELS

Starting in the seventies, research utilization has received much attention, and has been the subject of a number of major federally funded projects; some of these projects continue to the present in some evolved form. These research utilization projects each represent somewhat different approaches to bringing to bear research on the practice setting. They view research utilization as the last step in the research process, involving the steps of dissemination, evaluation, translation, adaptation, trial of innovation in relevant settings, diffusion and adoption. The models these projects utilize seem to place varying degrees of emphases on the characteristics and responsibilities of individual nurses vis-à-vis organizations and what their attributes need to be to bring about research utilization; they also concern themselves with characteristics of innovations that influence the likelihood of their adoption.

The projects reviewed below followed the seminal work by Ketefian in the early 1970s which demonstrated that research had hardly any impact on practice ${ }^{(2)}$, and where she discussed the issues in translation of scientific knowledge ${ }^{(3)}$.

Each of the models to be reviewed makes different assumptions about the resource system (those who produce the knowledge) and the user system (those who use/apply). In their approaches and inherent value systems they were influenced by models developed within agriculture, education, social sciences ${ }^{(4)}$, as well as within nursing ${ }^{(5)}$. As the complexity of the process of research utilization was recognized, innovation diffusion and knowledge utilization theory have shifted their emphasis from the individual to the social system or organizational level - dealing with features such as their readiness, propensity, characteristics, and other factors, which have become the subjects of analysis. Each of the six nursing projects and models is identified below ${ }^{(6)}$ :

1. The Regional Program for Nursing Research Development, sought to develop models to overcome barriers to research utilization ${ }^{(7)}$.

2. Nursing Child Assessment Training Project; a model was developed for diffusion and use of research-based innovations ${ }^{(8)}$.

3. Conduct and Utilization of Research in Nursing Project (CURN). The project focused on locating and disseminating research findings, and enabling organizational changes needed for effective research utilization. This project was located at the University of Michigan School of Nursing, with the investigators serving on the nursing faculty ${ }^{(9)} ; 17$ Michigan hospitals and the Michigan Nurses Association were participants.

4. Research Utilization in Nursing (RUN). This project involved evaluation and assessment of various features of the above three projects, comparing the projects with regard to specified variables, their effects over time (2-10 years), and overall use of research ${ }^{(10)}$. 5. Moving New Knowledge Into Practice Project. This project established practice-oriented conferences that brought together 
researchers with administrators and clinicians to emphasize dissemination and transfer of information; it has an evaluation component as well ${ }^{(11)}$.

6. Orange County Research Utilization in Nursing Project (OCRUN). Provides carefully designed research utilization continuing education to administrators, clinicians and staff nurses, and fosters interorganizational collaboration ${ }^{(12)}$.

\section{RESEARCH UTILIZATION AT THE INSTITUTIONAL LEVEL}

Given the nature of much of research-based practices, and the magnitude of what is involved in the change process, it is not sufficient for individuals to change their behavior to adopt and implement research in their practice. Rather, it is necessary for the organization to adopt the innovation and to do so in a planned and organized way. Different organizational characteristics may affect positively or negatively the different phases of the innovation process. For example, Rogers hypothesized that low centralization, high complexity, and low formalization may facilitate the initiation phase of the innovation process, but these very qualities may make it difficult to actually implement the innovation ${ }^{(13)}$. Thus, an understanding of our own organizations and appropriate interventions at various points in the change process becomes a critical factor in our success in bringing proposed innovations to reality.

There is now compelling evidence that the work environments exert a great deal of influence on individual nurses and their practice behaviors; thus, to facilitate use of scientific knowledge the practice environment needs to be shaped to support and enhance the individual nurse's capacity for innovation and creativity. In my own research on the ethical practice of nurses (taken here as an index of high quality nursing practice), I found that ethical practice conformed to higher professional standards when nurses perceived high peer cohesion, supervisor support, high work autonomy, and encouragement of innovation in the setting ${ }^{(14)}$.

The review of studies in acute care hospitals ${ }^{(15)}$, linked positive organizational outcomes to organizational climate and structure, in critical care settings ${ }^{(16)}$. Another example ${ }^{(17)}$ of how critical care nursing delivery structures and patterns can have positive clinical and cost-effective outcomes.

An organization's decision to engage in systematic use of research-based knowledge into practice results in important organization-wide changes that in turn enhances the staff nurses' ability to apply research in their practice. An example of this type is the Orange County Research Utilization in Nursing (OCRUN) ${ }^{(12)}$. This project involved a network of 20 nursing service organizations and six academic institutions, and was aimed toward building organizational capacity for research use. The investigators started with the premise that the innovation adoption potential (or organizational change capacity) of nursing service: "may be enhanced by strengthening the role-specific research use knowledge and skill of nurse employees. Also, by developing organizational infrastructure that supports strategic research utilization processes/activities, nurses within an organization become accountable for actively promoting clinical quality and effectiveness through scientifically based

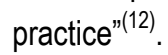

The authors evaluated five federally-funded projects on research utilization that were implemented between 1975 and 1985. Communication behavior, organizational change, individual change and education are at the core of the research utilization model described. Also, position-related responsibility and role assignment with responsibility for use of research strongly influenced research use behaviors of nurses. Each nursing service selected its own research utilization projects from the list provided by the project. As a result of their participation there was an increase in the number of institutions that established a nursing research committee. Nurse executives reported the following ways in which their organizations were affected: department being more research oriented, more scientific approach to both collecting and using clinical data, research involvement enhancing the organization's image, increased participation of nurses in research, enhanced image of organization by benefiting patients, more systematic way of carrying out changes, and showing others the effectiveness of nursing practice ${ }^{(12)}$.

A decade ago, under the auspices of the Federal government (U.S.), clinical practice guidelines were developed to assist in the prevention, diagnosis, treatment and clinical management of health conditions. These guidelines had an important impact on the practice of medicine and nursing at the level of health care institutions. As a result of this work and the methodologies that were used, knowledge synthesis approaches became well-known and respected. The approaches to knowledge synthesis that were used were labeled as narrative, consensus, and quantitative. Narrative synthesis is done by one person and entails a descriptive interpretation of a group of studies. Consensus synthesis, results from a panel of experts who combine research results with their professional experience. The quantitative, also known as meta-analysis, involves statistical analyses ${ }^{(18)}$.

Meta-analysis. T.S. Eliot asked in his poem "The Rock," "Where is the knowledge we have lost in information?" Indeed, there is no dearth of information. The challenge is how to extract knowledge from information. "Before what has been found can be used, before it can persuade skeptics, influence policy, affect practice, it must be known. Someone must organize it, integrate it, extract the message" ${ }^{\prime \prime(19)}$. Glass coined the term meta-analysis to refer to a systematic method for summarizing the results of independent research studies "for the purpose of integrating the findings". This rigorous method is distinguished from the traditional manner of 
reviewing the literature. Meta-analysis has come to be regarded as having made an important contribution to the advancement of knowledge, and is now being taught in a number of doctoral programs as an accepted and important research methodology.

Various combinations of the three knowledge synthesis methods have now become necessary precursors before research utilization can take place. This typically means the involvement of groups of people with different expertise, individuals such as clinicians, methodologists, administrators and others, so that judgments can be made about the validity and feasibility of the findings; in some instances, the need for additional studies might be suggested ${ }^{(18)}$.

In a recent study some authors investigated the barriers practicing nurses perceived to their using research findings in practice ${ }^{(20)}$. Table 1 lists 18 barriers that were reported by $50 \%$ or more of the respondents; 14 of these relate to the oganization or the research enterprise, and four relate to nurse features ( $\# 3,9,10,14$ ). This analysis suggests the critical role of organizations in facilitating or hindering research utilization practices of nurses.

Table 1 - Perceived Barriers by Nurses to Use of Research Findings ${ }^{(20)}$

1. Not enough auhority to change patient care procedures $752 \%$

2. Insufficient time to implement nein ideas $75.1 \%$

3. Nurse is unawure of the research $\quad 74.7 \%$

4. Physicians will not cooperate with implementation $\quad 71.2 \%$

5. Administation nill not allow implementation $70.6 \%$

6. Other staff are not supportive of implementation $\quad 70.5 \%$

7. Results not generalizeable to olun setting $68.3 \%$

8. Facilities inadequate for implementation $67.9 \%$

9. Statistical analrses not understandable $\quad 67.8 \%$

10. Nurse coes not have time to read research $\quad 67.2 \%$

11. Nurse isolater from knowuledgeable colleagues witt whom $65.2 \%$

to discuss research

12. Relevant litercture not compiled $n$ one place $\quad 63.1 \%$

13. Implicatons for pratice not made clear $61.5 \%$

14. Nurse does not feel capable of evaluating research qualitr. $59.3 \%$

15. Research has not been replicated $56.1 \%$

16. Research not reported clearly and readably $\quad 53.6 \%$

17. Research not relevant to nurse's practice $53.5 \%$

18. Nurse fels benefits of changing practice will be minimal $51.8 \%$

\section{USE OF RESEARCH FOR PUBLIC POLICY AND HEALTH POLICY}

With the establishment of the National Institute of Nursing Research at the National Institutes of Health, our awareness of the importance of developing a national strategy for bringing to bear research findings on health policy deliberations has become very keen indeed; given the climate in the US, where both the public and legislators at all levels are highly cognizant of the need for health care reform, development of a healthy health policy, broadly conceived, has assumed signal importance.

Three different types of research are thought to influence health policy ${ }^{(21)}$ : health policy analysis research, policy research, and disciplinary research. Of particular interest for our purposes is disciplinary research, and we will focus on it. An example of a disciplinary study that has had major policy impact - both national and institutional policy ${ }^{(17)}$. These investigators conducted a study of preterm infants. The control group of babies remained in neonatal intensive care settings until they reached a specified weight; the experimental group of babies were discharged early, but under the management of a neonatal clinical nurse specialist. This latter group did as well as the group that remained in intensive care, with regard to various outcome indicators, and considerable cost savings. The findings of this study are being used extensively throughout the country, and have led to considerable cost savings for hospitals. In addition, this study has provided the model for further work in early discharge with other types of patients.

Much research in the discipline of nursing is thought to have policy implications - if framed in a manner that make the research findings accessible to policy processes and policy makers. Once established, the Institute set about to develop a national nursing research agenda. Groups of experts were assembled, objectives were set; these panels established priorities on areas that could "provided a substantiated body of knowledge concerning specific health care problems and issues"(21). These priorities became the basis for focusing resources on the identified areas. This agenda has been revised from time to time, and has served as a guide to action and resource allocation.

This description provides but one example of how priority setting, resource allocation, and the conduct of research, can be framed and staged in such a manner that make nursing research policy-sensitive and amenable to use.

\section{RECOMMENDATIONS}

Where do we go from here? I submit a few suggestions for consideration.

1. The profession needs to be more active in targeting the areas in which research is desired, using patient needs and societal needs as the springboard for such targeting. The quantity of practice-oriented research has increased in the nursing literature. Moody and colleagues analyzed a decade of research (1977-1986), and found 720 articles dealing with aspects of nursing practice. Of these, " $64 \%$ were assessment-focused and $36 \%$ were intervention-focused" ${ }^{\text {"(22) }}$, which represented an increase of six times the number in the preceding decade. Thus, there is more research now than ever before that can be used for patient care improvement, but even more high quality and intervention-based research is needed.

2. We need an international network that enables research done in any part of the world to be accessible to users anywhere. Given the 
developments in technology, such as the Internet, the World Wide Web, we now have the means. What remains to be done is for nursing to organize a system for such sharing, and for maintaining its currency. This is a task for the International Council of Nurses and international nursing organizations. Sigma Theta Tau International, nursing's Honor Society, has already made an important start in this regard; members of the Society can now receive regular electronic mailings that provide information on new books and articles in their chosen area of interest. 3. There are now various national and international structures and institutions that review and evaluate research to determine what evidence, if any, has accummulated, if any, in order to provide the basis for evidence-based practice. Randomized clinical trials (CRTs) have become the gold standard in including studies in such reviews. However, there are very few studies in nursing that use RCTs as their methodology. There is much research in the profession that use descriptive, quasi-experimental and experimental designs. Nursing needs to carefully assess whether the RCT standard for meta-analytic reviews serves it well, or whether alternative approaches need to be used. This is an important issue for the profession internationally.

4. In order for researchers to produce practice-relevant research the involvement of those in practice is essential. This is an area requiring close collaboration. Collaboration at other points is crucial as well. Activities such as evaluation and synthesis of research, and for making appropriate and practice-sensitive translations require the input of academic researchers.

5. We need to have well developed mechanisms in place for identifying relevant research, evaluating, translating, testing and putting these into use. This can be done both at the international and institutional levels.

6. Evaluations of different systems for research utilization is needed. I have not emphasized the individual's role and factors within the individuals in this paper, but ultimately, everything depends on the individual nurse as the pivotal point where knowledge is brought to bear on patient care. Invites research comparing various utilization processes applied to individuals and organizations, in an effort to better understand what interactions might exist between individual and organizational characteristics that might optimize adoption of

\section{REFERENCES}

1. American Association of Colleges of Nursing. The essentials of master's education for advanced practice nursing. Washington (DC): Author; 1996.

2. Ketefian S. Application of selected nursing research findings into nursing practice. Nursing Research 1975a; 24:89-92.

3. Ketefian, S. Problems in the dissemination and utilization of scientific knowledge: How can the gap be bridged? In: Ketefian S., editor. Translation of theory into nursing practice and education, with a bibliogaphy on change. New York: New York University; 1975b. research-based innovations ${ }^{(6)}$

7. We need more research that test the effects of nursing interventions on patient outcomes. In other words, what difference does it make to patient well-being to receive a specific type of care? These types of studies can document the value of nursing care to patients and provide data on the basis of which funding for specific care and for reimbursement for nursing services can be justified.

8. We need more research that is cost-sensitive. Accountability seems to be the order of the day everywhere, regardless of the particular health care system. In comparing methods A and B for care, for example, we need to know not only what patient outcomes might ensue, but how much each will cost so that decision makers can take this important factor into account.

9. Nurses need to write and speak in various media to reach the general public as well as policy makers. These strategies disseminate our science more widely, and enhance the possibility that others will use the knowledge. The area of health promotion research especially lends itself to applications by the general public in cultivating personal habits and practices that can lead to health.

Many of these recommendations are contingent on our ability to provide the needed leadership, and our ability to create learning organizations. Senge has provided the framework for the learning organization:

"A learning organization ... is continually expanding its capacity to create its future. For such an organization, it is not enough to merely survive. 'Survival learning' ... is important ... But for a learning organization ... [it]must be joined by 'generative learning,' learning that enhances our capacity to create"(23).

Leaders must harness the forces of change, and stay focused on the purposes of the organization. They themselves must learn to be comfortable with uncertainty, and role model this behavior to others. As leaders in our respective settings, we have much to do.

National bounderies are crumbling and becoming meaningless. I see the truth about the term "Global Village." As an advocate of global cooperation and global collaboration, I hope that we will be able to learn from, support, and assist one another as we each work toward improving the health of all people.

4. Rogers $E$, Shoemaker F. Communication of innovations. $2^{\text {nd }}$ ed. New York: Free Press; 1971.

5. Stetler CB. Refinement of the Stetler/Marram Model for application of research findings to practice. Nursing Outlook 1994; 42(1):15-25. 6. Donaldson NE. If not now, then when? Nursing's research utilization imperative. In: Area Health Education Centers, University of Arkansas for Medical Sciences, editor. Dissemination strategies for changing clinical behavior. Little Rock: Author; 1993. p. 1-10. 
7. Krueger J, Nelson A, Wolanin M. Research utilization, part III, in nursing research development, collaboration and utilization. Germantown (MD): Aspen Systems; 1978.

8. King D, Barnard K, Hoehn R. Disseminating the results of nursing research. Nursing Outlook 1981; 24:164-9.

9. Horsely J, Crane J, Crabtree M, Wood D. Using research to improve nursing practice: A guide. New York: Grune and Stratton; 1983.

10. Crane J, Horsely J, Stewart B, Sheppard P. The research utilization survey instrument. Poster presented at WSRN, Denver, CO.

11. Funk $S$, Tornquist $E$, Champagne $M$. A model for improving the dissemination of nursing research. Western Journal of Nursing Research 1989; 11(3): 361-7.

12. Rutledge DN, Donaldson NE. Building organizational capacity to engage in research utilization. Journal of Nursing Administration 1995; 25(10):12-6.

13. Rogers EM. Diffusion of innovations. $4^{\text {th }}$ ed. New York: Free Press; 1995.

14. Ketefian S. Moral reasoning and ethical practice in nursing: An integrative review. New York: National League for Nursing; 1988.

15. Scott WR, Shortell SM. Organizational performance: Managing for efficiency and effectiveness. In: Shortell SM, Kaluzny AD, editors. Health care management: A text in organizational theory and behavior. New York: Wiley; 1983. p. 419-55.
16. Mitchell PH, Armstrong S, Simpson TF, Lentz M. American Association of Critical Care Nurses demonstration project: Profile of excellence in critical care nursing. Heart and Lung, The Journal of Critical Care 1989; 18(3):219-37.

17. Brooten D, Kumar S, Brown L, Butts P, Finkler S, Bakewell-Sachs $S$ et al. A randomized clinical trial of early discharge and home followup of very low birthweight infants. New England Journal of Medicine 1986;315:934-9.

18. Floyd JA. Knowledge synthesis - What is it? Michigan Nurse, September.

19. Glass G.V. Primary, secondary, and meta-analysis of research. Educational Researcher 1976; 5(11): 3-8.

20. Funk SG, Champagne MT, Wiese RA, Tornquist EM. Barriers to using research findings in practice: The clinician's perspective. Applied Nursing Research 1991; 4(2):90-5.

21. Hinshaw AS. The impact of nursing science on health policy. In: Communicating nursing research, Volume 25, Silver Threads: 25 years of nursing excellence. Boulder (CO): Western Institute of Nursing; 1992.

22. Moody L, Wilson M, Smyth K, Schwartz R, Tittle M, Van Cott M. Analysis of a decade of nursing practice research: 1977-1986. Nursing Research 1988; 37(6):374-9.

23. Senge PM. The fifth discipline. New York: Doubleday; 1990. 